\title{
Optimal Incentive Design of Wellness Programs That Encourage Behavior Change to Health Improvement in Health Insurance Subscriber*
}

\author{
Masaru Unno ${ }^{\mathrm{a}, \dagger} \quad \mathrm{Hua} \mathrm{Xu}^{\mathrm{b}}$

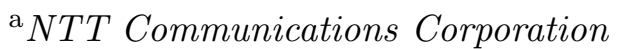 \\ ${ }^{\mathrm{b}}$ Graduate School of Business Science, University of Tsukuba
}

\begin{abstract}
In recent years, a number of health insurers have introduced a reward gain type of wellness programs that can reduce the medical costs by encouraging the behavior change of health insurance subscribers to improve health. In the programs, insurers have to determine a reward strategy in order to strive the insurance subscribers. In this paper, we study the insurer's incentive designing problem of wellness programs. We formulate the insurer's incentive designing problem as a dynamic principal-agent problem. We derive the sufficient conditions for the existences of the optimal reward strategy, the optimal health-support service strategy, and the incentive compatible effort recommended to the insurance subscribers. We also discuss the effects of the insurer's risk-sensitivity on the optimal strategies. We use a numerical example to show the computation aspects of the problem.
\end{abstract}

Keywords: Agency problem; Optimal contract; Risk-sensitive stochastic control; Health insurance; Wellness program

\footnotetext{
*Received: June 27, 2016; Accepted: March 3, 2017.

${ }^{\dagger}$ Corresponding author. Address: Takebashi Bldg. 1-2-2 Hitotsubashi, Chiyoda-ku, Tokyo 100-8128, Japan; Phone: +81-3-6701-2760; E-mail: masaru.unno7@gmail.com
} 


\title{
医療保険加入者に健康改善への行動変容を促すウェルネス・プログラムの 最適インセンティブ設計
}

\author{
海野 大 $^{\mathrm{a}} \quad$ シュウファ ${ }^{\mathrm{b}}$ \\ ${ }^{\mathrm{a} N T T}$ コミュニケーションズ株式会社 \\ $\mathrm{b}$ 筑波大学大学院ビジネス科学研究科
}

\section{1 はじめに}

日本は世界有数の長寿国であるが，出生率（合計特殊出生率）の低下により急速に高齢化が進んでお り，2050 年には 65 歳以上人口が全国民の 4 割近くになる見込みである ${ }^{1}$. これに伴い医療費も増加を続 け，2013 年度の国民医療費は対前年 8493 億円増の 40 兆円に達している ${ }^{2}$. 医療費の $57.7 \%$ は 65 歳以 上の高齢者によるもので，高齢化の進展で今後も増大する見込みである．また，医療費の $38.8 \%$ は公費 （国，地方）によって賄われており ${ }^{3}$ ，今後生産年齢人口が急激に減少していく中で，医療費の抑制は日 本にとって喫緊の課題となっている.

ところで，日本の平均寿命は世界一で男女それぞれ 80.50 歳， 86.83 歳であるが 4 , 健康寿命（健康上 の問題で日常生活が制限されることなく生活できる期間）はこれよりも 10 年程度短く, 男性が 71.19 歳, 女性が 74.21 歳となっている ${ }^{5}$. 高齢者の医療費の大半がこの平均寿命と健康寿命の差の期間に支出され ていることになる，従って，医療費の抑制はいかにして健康寿命を延伸し平均寿命に近づけられるかに よっている．また，医療費のうちの医科診療医療費の $34.9 \%$ は生活習慣病に関わるものであり ${ }^{6}$, これ らの疾病は 65 歳以上の高齢者の死因の上位を占めている 7 . つまり, 生活習慣病への罹患を予防するこ とによって健康寿命を延伸することができ，その結果，個人としてもより充実した生活を送れるととも に，医療費の抑制が期待できるのである.

生活習慣病の予防には適切な食生活や運動など健康を改善する行動をとらなければならないが，必ずし も多くの人がこのような行動をとっているわけではない. 実際，40歳以上の男性の $50 \%$ ，女性の $20 \%$ メタボリックシンドローム（内臟脂肪症候群）該当者もしくは予備群と推定されている8.

1国連による予測（「World Population Prospects， the 2015 Revision」）によれば，2050 年における主要国の高齢（65 歳 以上) 人口比率は, 日本 : $36.3 \%$, 韓国 : $36.2 \%$, ドイッ : $32.3 \%$, 中国 : $27.6 \%$, フランス: $26.3 \%$, イギリス : $24.7 \%$, アメ リカ : $22.2 \%$ どとなっている.

${ }^{2}$ 政府統計「平成 25 年度国民医療費」による，なお，国民医療費とは，医科診療医療費（入院，入院外），歯科診療医療費， 入院時食事・生活医療費, 訪問看護医療費, 療養費, 薬局調剂医療費など, 保険診療の対象となる得る傷病の治療に要する費 用をいう。国民医療費は 2000 年度の 30 兆円から 2013 年度の 40 兆円まで約 10 兆円（年平均 $2.2 \% ）$ の増となっている.

政府統計「平成 25 年度国民医療費」によれば，国民医療費の財源別構成は次の通り：国庫 $25.5 \%$ ，地方 $12.9 \%$ ，保険料 （事業主） $20.3 \%$ ，保険料（被保険者） $28.5 \%$ ，患者負担 $11.8 \%$.

4 厚生労働省「平成 26 年簡易生命表」（2015 年 7 月 30 日）による.

${ }^{5}$ 内閣府「平成 28 年版高齢社会白書」（2016 年 5 月 20 日）による.

${ }^{6}$ 生活習慣病にかかる医療費とは，医科診療医療費のうち「悪性新生物」，「高血圧性疾患」，「心疾患（高血圧性のものを除

く）」,「脳血管疾患」,「糖尿病」にかかるものである.

7 厚生労働省「平成 26 年簡易生命表」（2015 年 7 月 30 日）による.

${ }^{8}$ 厚生労働省「平成 18 年国民健康・栄養調査」による. 
こうした状況を背景に，日本政府は 2000 年に生活習慣病やその原因となる生活習慣の改善等を目的 として「21 世紀における国民健康づくり運動（健康日本 21）」を策定し，その法的基盤となる「健康増 進法」を 2003 年に施行した。また，2008 年からはメタボリックシンドロームに着目した「特定健康診 查・特定保健指導」9 が導入され，2013 年には健康寿命延伸をその中心的課題に据えた「21 世紀におけ る第二次国民健康づくり運動（健康日本 21 (第二次) )」が開始されている。ささらに，2015 年に施行さ れた「持続可能な社会保障制度の確立を図るための改革の推進に関する法律（2013 年成立）」や，同年 の医療保険制度改正などにより，各医療保険者の保健事業の中に「健康管理及び疾病の予防に係る自助 努力への支援」が位置付けられ，加入者個人へのインセンティブを提供する取組（加入者の予防・健康 づくりに向けた取組に応じてへルスケアポイント付与や保険料への支援等を行うこと $\left.{ }^{10}\right)$ を含め，加入 者自身の自助努力を支援する取組を進めることが期待されている.

これらの一連の政府の政策を踏まえ，多くの自治体（国民保険）や健康保険組合では，住民や保険加 入者向けに健康改善のためのウェルネス・プログラムを提供し始めている. ウェルネス・プログラムと は, 保険加入者などが自らの健康改善に対して積極的に取り組めるょうな環境や仕組みのことで, 具体 的には健康診断やレセプトデータの分析などに基づく食事・運動等の個別健康アドバイス, 健康・医療 講座開催, 無料のスポーツ教室やスポーツジムの割引料金による利用といった健康サポートサービスで ある．保険加入者がこのようなウェルネス・プログラムに積極的に参加し，日々の生活の中で健康状態 の改善に努めるようになれば，生活習慣病を予防できるようになり，結果として医療費を抑制すること が可能になる，なお，健康状態は血圧や BMI，血糖值，コレステロール值等を測定することで評価でき， それによって健康寿命を推定することができる，例えば，Yatsuya et al. [10] は性別や年齢，喫煙有無， 糖尿病有無，並びに血圧やコレストロール值等の健康診断データに基づく心筋梗塞や脳梗塞発症確率予 測モデルを開発，検証している.

健康改善に努めるということは，食生活を始めとして，勤務時間後や休日の過ごし方など日常の細か な行動を変えることであり，決して容易なことではない，現に疾病に罹患しておらず，健康面で自立した 生活を送っている加入者の行動を変容させるためには，単に健康改善への漠然とした欲求以上の何らか 強いインセンティブが必要である。そこで，いくつかの自治体や健康保険組合では，2015 年度医療制度 改正などを踏まえ, 保険加入者が健康改善に努めるとその結果（運動量や摂取カロリー量, 血圧や BMI, 血糖值等の健康状態指標の改善状況，あるいは生活習慣病への非罹患等）に応じて報奨（ヘルスケアポ イント (ヘルスマイレージ) やクーポン等）を与える制度を組み込んだウェルネス・プログラムを提供 し始めている ${ }^{11}$. また，公的保険だけでなく，健康改善度などに応じて保険料の割引やポイント等を付 与するウェルネス・プログラムを医療保険のオプションとして提供する民間保険会社もあり, Discovery 社（南アフリカ共和国）の Vitality Program [9] が世界的に有名である ${ }^{12}$.

先行研究によれば，このような報償制度がウェルネス・プログラムへの積極的な参加を促すインセン

\footnotetext{
${ }^{9}$ 特定健康診査（特定健診）とは，生活習慣病の発症や重症化の「予防」を目的として，医療保険者（国民保険・被用者保 険）が実施主体となって 40 歳〜 74 歳の加入者（被保険者・被扶養者）を対象に生活習慣病の発症前の段階であるメ夕ボリッ クシンドロームの該当者やその予備群を発見するための健診。また，特定保健指導は，特定健診の結果により生活習慣病の発 症リスクが高く，生活習慣の改善による生活習慣病の予防効果が多く期待できる人に対し，医師，保健師，管理栄養士等の専 門家が対象者の身体状況に合わせた生活習慣を見直すためのサポートを実施するもの.

${ }^{10} 2016$ 年に厚生労働省により「個人の予防・健康づくりに向けたインセンティブを提供する取組に係るガイドライン」が策 定され，加入者個人にインセンティブを提供する場合の留意点が示されている（金銭的価值が高額となるインセンティブは避 ける，等).

11静岡県の「健康マイレージ」, NTT 健康保険組合（NTT Kenpo Smart Life Park）の「ヘルスマイレージ」など.

12 加入者が, web での健康チェックやウェアラブル端末によって収集される健康データや提携医療機関での健康診断結果など に基づき運動や食事制限などの健康改善行動を行い，その成果（運動量や血圧，血糖值等の健康状態改善状況）に応じてホテ ルや航空券などが割引になるクーポンを受け取れるサービスであり, 南アフリカの他英国などで多くの利用者を獲得している. また，日本でも住友生命相互会社，ソフトバンク株式会社と提携し，同様のサービス提供に向けた取り組み（Japan Vitality Project）を開始する旨 2016 年 7 月に発表している.
} 
ティブとして有効であること，そして，ウェルネス・プログラムが医療費の抑制に効果的であることが認 められている. Merrill et al. [6] は，米国ユタ州ソルトレイクシティの市職員（約 4,000 名，平均年齢約 46 歳) についてウェルネス・プログラムの参加状況について調査し, 参加への動機付けとなる最も強い 要因は報償金であり，2004 年から 2008 年にかけてウェルネス・プログラムの参加率が $10 \%$ イント向 上し，この 5 年間で医療費が約 3.6 百万ドル削減（ウェルネス・プログラムの運営費用と報奨に要する費 用を除いた純削減額．なお，総費用に占める報償の割合は約 70\%）されたとしている。また， Lambert et al. [5] と Patel et al. [7] は, Discovery 社の Vitality Program に参加し運動などの健康改善に努めた 保険加入者は，そうでない加入者と比較し健康状態が良好となり，医療費が抑制されたとしている.

ところで, 報償が保険加入者にウェルネス・プログラムへのインセンティブとして有効であるとして も，無限に報償を提供することはできない. 民間保険会社に健康保険組合や国民保険も含めた広義の医 療保険者がこのような報償提供型のウェルネス・プログラムを提供することによるメリットは, 保険加 入者に健康改善に努めるように行動変容を促すことで生活習慣病などへの罹患率を低下させる，すなわ ち加入者の健康寿命を延伸させることにより，保険金（国民保険や健保負担分の医療費と保険会社が支 払う保険金をまとめて保険金と呼ぶこととする）の支払額を抑制できることである。すなわち，保険金 支払いの抑制額からウェルネス・プログラムの運営経費と報奨を除いた差額を保険者の収益と呼ぶこと にすると，ウェルネス・プログラムのメリットとは保険者が正の収益を得られることである，このメリッ 卜を実現するためには，加入者にできるだけ健康改善の努力をさせなければならないが，より大きな努 力をさせるためには報償をより大きくしなければならず，最終的に保険者が保険金支払いを抑制するこ とによって得られる増分収益は減少する。国民医療費を可能な限り削減するためには保険者のこの増分 収益を最大化しなければならず，従って，保険者は自らが得る収益を最大化するために加入者にどれだ けの努力をさせてどれだけの報償を提供するべきか，すなわち最適なインセンティブ・メカニズムを設 計する必要がある.

本論文では，上述の最適なインセンティブ・メカニズムの設計問題をエージェンシー問題と捉え研究 する，保険者は報奨提供型ウェルネス・プログラムを加入者に提供することを通じて, 加入者が健康改 善努力を行うよう暗示的に委託しており, よって, 保険者と加入者の関係はプリンシパルとエージェン トの関係と見なすことができる，加入者には，健康改善努力を継続しても，職場や生活環境から与えら れるストレスや受動喫煙, 未解明の遺伝的要因など加入者の努力によらない不確実な要因によって健康 状態指標が悪化したり生活習慣病に罹患することがあるため, 努力に応じた報奨を得られない可能性が ある。一方, 保険者は加入者がどれだけ健康改善努力を行っているか観察困難である. さらに，加入者 の健康改善努力に対する意欲の高さには不確実性が存在し，加入者が報酬に応じた努力を行わないこと があるため，保険者には提供した報酬に応じた収益を得られない可能性がある。このように，保険者， 加入者共にリスクに直面しており, 保険者はこのような状況下で最適なインセンティブ・メカニズムを 設計しなければならない. 以下，第 2 節で最適なインセンティブ・メカニズムの設計問題を, Sannikov [8]の方法を応用した動的プリンシパル-エージェント・モデルとして定式化する. 特に，プリンシパルで ある保険者及びエージェントである加入者が共にリスク回避的なケースを考え ${ }^{13}$, Başar and Bernhard [1] によるリスク-センシティブ確率制御問題として定式化を行うこととする. 第 3 節でこのリスク-セン シティブ確率制御問題を解析し, 最適報奨戦略, 最適努力水準及び最適サポート戦略を求める. 第 4 節

\footnotetext{
13保険者には公的医療保険（国民健康保険，企業の健康保険組合等）が含まれるため，本論文ではプリンシパルもリスク回 避的と仮定している。一般に，公的規制を受ける企業や組織は事業活動の内容や範囲について行為規制を受けており，事業運 営に対する意思決定にあたってはその決定が規制に抵触しないか常に自己チエックを行う必要があるため, 公的規制を受けて いない企業に比しリスク回避的な行動を取らざるを得なくなる傾向がある. 公的医療保険の保険者は公的資金（国や地方自治 体の税金等）が直接投入されているために種々の公的規制を受けており，特に，厚生労働省の「個人の予防・健康づくりに向 けたインセンティブを提供する取組に係るガイドライン（2016 年制定）」に報奨の提供によって保険給付に支障を生じるよう な事態を避ける旨規定されていることから，財務的リスクを回避する意思決定行動を取ると考えら机る。
} 
では数值シミュレーションによって問題解決の可能性を示し，第 5 節では保険者のリスク感度が最適解 に与える影響を考察する。第 6 節は結論である。

\section{2 問題の定式化}

今，医療保険者が加入者に，運動や食事に注意した健康改善行動をとることで健康寿命が延びれば報 奨を支払うというウェルネス・プログラムを提供するものとする．加入者が健康改善のための努力を行 い，その結果生活習慣病に罹患せず健康寿命が伸びれば，保険金を支払わなければならない可能性が低 下し，保険者は収益を拡大できる。保険者としては，加入者が健康寿命を伸ばすために最大限の努力を 遂行するようなインセンティブ・メカニズムを設計したい.

保険者が最大化したいのは，直接的には保険金支払いの抑制額であるが，ここでは加入者の健康寿命 を金銭的価值を有する一種の資産と考え，保険者はこの資産としての健康寿命を最大化したいものとす る ${ }^{14}$.この問題を定式化するために平均余命関数を考える. 平均余命とは時刻 $t$ における加入者の残存 寿命であるが，ここでは健康寿命を平均余命関数によって表すことにする ${ }^{15}$. 平均余命関数は生存関数 によって表すことができる．生存関数を $S(t)$ と書く．生存関数とは，時刻 $\tau$ まではあるイベント（ここ では生活習慣病の罹患）が発生しない確率のことであり， $S(\tau)=\mathbb{P}(T>\tau)$ と定義される. 今，時刻 0 をウェルネス・プログラムの開始時点とする。このとき，時刻 $0 \leq t$ における平均余命関数は

$$
L(t)=\frac{\int_{t}^{\infty} S(s) d s}{S(t)}
$$

の形に表される．この $L(t)$ は，時刻 $t$ 以降においてウェルネス・プログラムに参加せず健康改善のため の努力を行わないとしたときの, 自然状態における健康寿命であるとする， $L(t)$ は $t$ の非増加関数であ る. 健康寿命は死亡時までの余命より長くはなり得ないことから， $L(t)$ には上限 $\bar{L}$ がある.

さて，保険者がウェルネス・プログラムを提供し，加入者がこのプログラムに参加して健康改善努力 を行うことにより，健康寿命に影響を及ぼすことができる，すなわち，保険者がウェルネス・プログラ ムによって提供する種々の健康サポートサービスがより多いほど，また，加入者がより多くの健康改善 努力を行うほど，加入者の健康寿命が長くなるものとする，なお，保険者は加入者の努力水準（運動量 や摂取カロリー量等）を観察できないものとする.

この状況を表現するために, 初めに準備として以下の離散時間モデルを考える. 期間は $[t, t+\Delta t]$ と し, $\Delta t$ は自然状態の健康寿命 $L(s), s \in[t, t+\Delta t]$ が無視し得る程度しか変化しない短い時間間隔であ るとする．今，加入者が $t$ 期にウェルネス・プログラムに参加したとする。 $t$ 期において保険者が単位 時間当たりに提供する健康サポートサービスを $\mu(t) \geq 0$, 加入者の行う単位時間当たり健康改善努力を $\eta(t) \geq 0$ とし, $g(\mu(t), \eta(t)) \geq 0$ によってサポートサービスと努力が健康寿命に与える影響度を表すもの とする. $g(\mu(t), \eta(t))$ は，健康サポートサービスと健康改善努力のいずれか，若しくは両方が正值をとる と正の值をとり，健康サポートサービスと健康改善努力の両方が 0 の場合，0 となるものとする．また， 加入者の努力水準が同一でも保険者の健康サポートサービスの提供量が大きいほど $g(\mu(t), \eta(t))$ の值は

\footnotetext{
14実務的には，資産としての健康寿命の金銭的価值は健康寿命が 1 単位延伸することにより削減される保険金支払あるいは 医療費（不健康期間（生活習慣病に罹患してから死亡するまでの期間）における，当該保険加入者の平均医療費）として評価 することができる。但し, 将来の医療費は 2 年ごとの診療報酬改定により変動し, また加入者集団の平均医療費も保険組合等 により異なる（地域性等）ため，実際に健康寿命の金銭的価值を評価する際は個別ケース毎に実施する必要がある。

15 生活習慣病は一旦罹患してしまうと完治が難しいとされおり，死亡に至らなくても，急性期後の長期間（若しくは一生涯） 投薬が必要となる場合が多く，その期間は医療費が発生する。ウェルネス・プログラムは加入者の健康寿命を延伸することに よって保険金支払額すなわち医療費を削減することを目的としており，医療費が生じている間は不健康状態とみなすべきと考 えられることから，本論文では健康寿命を平均余命関数を用いて表現する.
} 
大きくなり，保険者の健康サポートサービス提供量が同一でも加入者がより努力するほど $g(\mu(t), \eta(t))$ の值は大きくなるものとする.

ここで, ウェルネス・プログラム参加後の健康寿命を $X(s), s \in[t, t+\Delta t]$ とする. $t$ 期に健康サポー トサービスが提供され加入者が健康改善努力を行い， $t+\Delta t$ 期には健康サポートサービスの提供も努力 もなされなかったとき，健康寿命は

$$
\frac{X(t+\Delta t)-X(t)}{\Delta t}=-g(\mu(t), \eta(t)) L(t)
$$

のように変化する。 (2) 式は, $t$ 期に健康サポートサービスの提供と加入者の健康改善努力がなされたこ とにより， $t$ 期の時点における健康寿命が拡大し， $t+\Delta t$ 期におけるそれよりも大きくなることを示して いる．もし，保険者が健康サポートサービスを提供せず，加入者も努力を行わなければ $g(\mu(t), \eta(t))=0$ となり, 健康寿命は変化しない.

(2) 式の離散時間モデルは， $\Delta t \rightarrow 0$ とすることで連続時間モデルにすることができる :

$$
d X(t)=-g(\mu(t), \eta(t)) L(t) d t
$$

これは，保険者の健康サポートサービスと加入者の健康改善努力による健康寿命のダイナミクスである.

この健康寿命のダイナミクスは, 加入者の努力によらない不確実な要因, 例えば生活環境の変化など によって影響を受ける。そこで，健康寿命は次のブラウン運動に従うものとする：

$$
d X(t)=-g(\mu(t), \eta(t)) L(t) d t+\sigma d Z(t)
$$

ここで, $Z=\{Z(t) ; \mathcal{F}(t), 0 \leq t<\infty\}$ は標準ブラウン運動で, $\{\mathcal{F}(t), 0 \leq t<\infty\}$ は $\{X(t), 0 \leq t<\infty\}$ によって生成されるフィルトレーションである。 また， $\sigma$ は健康寿命の変動の度合いを示す定数である.

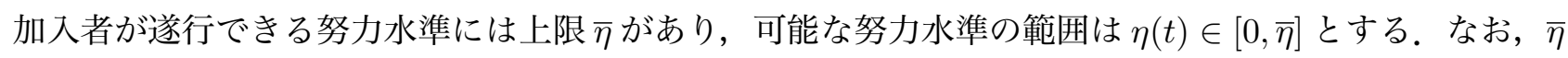
は十分大きな值に設定されているものと仮定する．保険者の健康サポートサービスの提供量にも上限 $\bar{\mu}$ があるものとする. よって, $(\mu(t), \eta(t)) \in[0, \bar{\mu}] \times[0, \bar{\eta}]$. 関数 $g(\mu(t), \eta(t))$ は $\mu(t), \eta(t)$ に関して厳密に 増加かつ凹で連続微分可能, $\frac{\partial g(\mu, \eta)}{\partial \mu}=g_{\mu}(\mu, \eta)<\infty, \frac{\partial g(\mu, \eta)}{\partial \eta}=g_{\eta}(\mu, \eta)<\infty$ とし, 保険者はその関数形 を知っているものとする.

加入者に健康改善努力を遂行させるために，保険者は努力水準に応じて報奨を支払う，報奨の源泉は 加入者の健康改善により抑制される保険金支払額であり，これは健康寿命の延伸量に比例する．そこで， 健康寿命の延伸量に応じて保険者が加入者に報奨を支払うものとしょう．加入者は，健康寿命の延伸に より保険者が抑制し得る保険金支払額を厳密に知ることはできないが，健康寿命は保険者，加入者いず れもが観察可能な共通の尺度である. 健康寿命の延伸量は (3) 式の両辺に -1 を乗じることで得られる.

今，時刻 $t$ に保険者から加入者へ支払われる報奨を $\gamma(t) \geq 0,0 \leq t<\infty$ で表す．加入者に支払われる 報奨は健康寿命の延伸により抑制される支払保険金を超えることはないから， $\gamma(t)$ には上限 $\bar{\gamma}(t) \geq \gamma(t)$ がある．加入者は $\gamma(t)$ を受け取ることで $u(\gamma(t))$ の効用を得るものとする．加入者はリスク回避的であ $\eta^{16}$, 効用関数 $u(\gamma(t))$ は増加かつ凹で連続微分可能, $u^{\prime}(\cdot)<\infty$ とし, $u(0)=0$ と正規化されているも のとする. また，加入者の留保効用は 0 とする. さらに, 加入者は $\eta(t)$ の努力を行うために, $h(\eta(t))$ の

\footnotetext{
${ }^{16}$ 加入者のウェルネス・プログラムにかかるリスク回避性については，例えば，厚生労働省「個人への予防インセンティブ 検討ワーキンググループ」の第 2 回会合（2015 年 10 月 28 日）における久野構成員 (筑波大学) の報告『健康づくり無関心 層も含めた行動変容事業としての健康ポイント』を参照。同報告（報告資料 7 ページ）で，インセンティブのタイプが確定型 (入会すれば報酬がもらえる), 努力型（日常の歩数に応じて）, 成果型（例：体重 $3 \mathrm{~kg}$ 減）の場合を比較し, 確定型は参加率 が高いが成果は努力型が他の 2 タイプより高い傾向にあるとされており，このことはウェルネスプログラム参加者の多くがリ スク回避的である（確実に一定額の報酬を得られる方を好む）ことを示すものと考えることができる.
} 
コストを負担するものとする ${ }^{17} . h(\eta(t))$ は効用 $u(\gamma(t))$ と同一の単位で測られ，厳密に増加かつ凸で連 続微分可能, $h^{\prime}(\cdot)<\infty$ とする. 保険者は加入者の効用関数, コス卜関数について観察可能と仮定する.

加入者が $\eta(t), 0 \leq t<\infty$ の努力を行うとき，加入者の総期待効用は

$$
\mathbb{E}\left[\int_{0}^{\infty} e^{-r t}(u(\gamma(t))-h(\eta(t))) d t\right]
$$

となる。但し， $r$ は割引率 18 .

一方，保険者には健康寿命の大きさに応じた契約管理費用 $\beta d X(t), \beta$ は定数と，提供する健康サポー トサービスの量に応じたオペレーション費用 $c(\mu(t))$ が発生するものとする。 $c(\mu(t))$ は厳密に増加かつ 凸で連続微分可能， $c^{\prime}(\cdot)<\infty$ とする。このとき，保険者の期待収益は

$$
\begin{aligned}
& \mathbb{E}\left[\int_{0}^{\infty}-e^{-r t} d X(t)-\int_{0}^{\infty} e^{-r t} \gamma(t) d t-\int_{0}^{\infty} e^{-r t} c(\mu(t)) d t-\int_{0}^{\infty}-e^{-r t} \beta d X(t)\right] \\
& \quad=\mathbb{E}\left[\int_{0}^{\infty} e^{-r t}((1-\beta) g(\mu(t), \eta(t)) L(t)-\gamma(t)-c(\mu(t))) d t\right] .
\end{aligned}
$$

さらに，保険者はリスク回避的であり ${ }^{19}$ ，この収益に対して以下の効用関数を有するものとする ${ }^{20}$ :

$$
\mathbb{E}\left\{-\exp \left[-\rho\left(\int_{0}^{\infty} e^{-r t}((1-\beta) g(\mu(t), \eta(t)) L(t)-\gamma(t)-c(\mu(t))) d t\right)\right]+1\right\}
$$

ここで， $r$ は割引率で，簡単のため加入者と同一とする．また， $\rho$ は保険者のリスク感度を表す定数であ り ${ }^{21}$ ，保険者の私的情報であるとする.

\section{1 保険者の問題}

加入者は保険者が提示する報奨の下で，自己の効用を最大化するように努力を行うものとする．保険 者は加入者の効用最大化行動を前提に，自らの収益を最大化するような健康改善努力水準を加入者に推 奨し，そして，実際に加入者に推奨努力水準を遂行させられる報奨を決定したい。これは，保険者の問 題は，加入者に対して留保効用 0 以上の効用を保証する参加制約

$$
\mathbb{E}\left[\int_{0}^{\infty} e^{-r t}(u(\gamma(t))-h(\eta(t))) d t\right] \geq 0
$$

を満たす $(\gamma(t), \eta(t))$ の組の中で，加入者の誘因両立制約

$$
\eta(t) \in \underset{\tilde{\eta}(t)}{\arg \max } \mathbb{E}\left[\int_{0}^{\infty} e^{-r t}(u(\gamma(t))-h(\tilde{\eta}(t))) d t\right]
$$

\footnotetext{
${ }^{17}$ 加入者が健康改善努力を行うために負担するコストには，運動のための金銭的負担（ウェアの購入費用やフィットネスク ラブの会費等）の他，食事制限などの精神的コストや余暇の時間を運動等の健康改善活動に費やすことの機会コストなどが含 まれる。

18割引率は外生的に与えられるものとするが，安全利子率を用いるのが妥当と考えられる。

19 脚注 13 にあるように，公的医療保険の保険者は公的規制を受けているためリスク回避的な行動を取らざるをえないと考 えられる。 ウェルネス・プログラムの提供にあたつては，加入者の健康改善努力の意欲の高さに不確実性が存在し，保険者は 加入者に提供した報酬に応じた収益を得られないリスクがあることから，保険者は過度の報酬提供に対して消極的，つまりリ スク回避的になると考えられる. 本論文では，このリスク回避的な行動を本式のように指数型効用関数によって表現する.

${ }^{20}$ 期待值は実確率測度による。

21 効用関数を $u(\cdot)$ とすると, リスク感度は $\rho=\left|\frac{u^{\prime \prime}(\cdot)}{u^{\prime}(\cdot)}\right|$ である.
} 
の下で保険者の期待効用

$$
\mathbb{E}\left\{-\exp \left[-\rho\left(\int_{0}^{\infty} e^{-r t}((1-\beta) g(\mu(t), \eta(t)) L(t)-\gamma(t)-c(\mu(t))) d t\right)\right]+1\right\}
$$

を最大化する加入者の努力戦略 $\{\eta(t), 0 \leq t<\infty\}$ と報奨戦略 $\{\gamma(t), 0 \leq t<\infty\}$ 及び健康サポートサー ビス戦略 $\{\mu(t), 0 \leq t<\infty\}$ を決定する最適化問題となる.

\section{2 加入者の継続価値}

保険者が加入者に推奨努力水準を遂行させるには，健康寿命の長さに応じて報奨を変動させればよい ように思われる。しかし，加入者の努力には費用がかかり，さらに，健康寿命の長さには不確実性があ るため, 加入者にはリスクがある。もし，結果としての健康寿命の長さに連動して加入者への報奨が決 まるならば，加入者は保険者に高いリスク・プレミアムを求めるであろう．それは保険者の収益を圧迫 するから，保険者にとって好ましくない方法である.

そこで, 加入者に推奨努力水準を遂行させるために, 加入者が時刻 $t \geq 0$ 以降の全期間に渡って得られ るであろう総期待効用に応じて報奨を変動させることを考える。この期待効用を顧客の継続価値と呼び, $W(t)$ で表す。さて, 保険者による任意の報奨戦略 $\gamma=\{\gamma(t)\}$ 及び健康サポートサービス戦略 $\mu=\{\mu(t)\}$ が与えられ，これに対して加入者が努力戦略 $\eta=\{\eta(t)\}$ をとるものとする. 今，時刻 $t, 0 \leq t<\infty ま$ での状態がわかっており， $(\gamma, \mu, \eta)$ に基づき $t$ 以降に報奨 $\{\gamma(s) \in[0, \bar{\gamma}(s)], t \leq s<\infty\}$, 健康サービスサ ポート $\{\mu(s) \in[0, \bar{\mu}], t \leq s<\infty\}$, 及び努力 $\{\eta(s) \in[0, \bar{\eta}], t \leq s<\infty\}$ が遂行されるとき, 時刻 $t$ におけ る加入者の継続価值は

$$
W(t ; \gamma, \mu, \eta)=\mathbb{E}^{\eta}\left[\int_{t}^{\infty} e^{-r(s-t)}(u(\gamma(s))-h(\eta(s))) d s \mid \mathcal{F}(t)\right]
$$

となる. $\mathbb{E}^{\eta}$ は加入者の努力戦略 $\eta$ から導かれる確率測度 $\mathbb{P} \eta$ の下での期待值である. 以下では，この継続価 值 $W(t ; \gamma, \mu, \eta)$ を唯一の状態変数として, 保険者と加入者の最適努力水準並びに最適報奨を導く. 誘因両 立制約から加入者は $W(t ; \gamma, \mu, \eta)$ を最大化する行動をとるので, 将来の報奨の変更を通じて $W(t ; \gamma, \mu, \eta)$ を変化させることにより, 保険者は加入者に任意の努力水準を遂行させることができる. $W(t ; \gamma, \mu, \eta) に$ は加入者が時刻 $t$ までに遂行した努力水準とその費用, 及びその結果として実現した健康寿命 $X(t)$ と 加入者に対する報奨の変遷が集約されているので, $W(t ; \gamma, \mu, \eta)$ によて報奨が決まる仕組みによって, 加入者に健康改善努力へのインセンティブを与えることができる.

ここで保険者は加入者の継続価值 $W(t)$ がいかなる值であっても, その時点における報奨に基づき設定さ れる解約金を加入者に支払うことによって，いつでもウェルネス・プログラムを解約できるものと仮定する. 解約金は, その時点の継続価值 $W(t)$ によって決定され, 解約時の保険者の值関数を $\Omega(W(t))=-\xi \gamma(t)$ とする. 但し, $\xi$ はある定数で, $\Omega(0)=0$ とする. 契約解約後は加入者は努力を行わないから, 時刻 $t$ に解約されたときの加入者の期待効用は,

$$
W(t)=u(\xi \gamma(t))
$$

となる。

保険者は $W(t)$ が極端に大きくなると, ウェルネス・プログラムを解約するものとする ${ }^{22}$. なぜなら,

22 多くのウェルネス・プログラムには報奨に利用期限を設けており，また，厚生労働省の「個人の予防・健康づくりに向け たインセンティブを提供する取組に係るガイドライン (2016 年制定)」には，報奨の金銭的価値が高額になりすぎないように すること, 並びに加入者が当初は報奨によって健康改善努力を開始し継続しているとしても, 本人の健康改善意識を高めるこ とによって将来的には報奨なしでも努力を継続させることを目標とすることが規定されており，W $(t)$ が極端に大きくならな いような歯止めがかけられている。 ウェルネス・プログラムに関する解約条件は，これらに基づき，モデルの分析のためにお いた理論的な仮定である。 
$W(t)$ は加入者の努力によって健康寿命 $X(t)$ が長くなれば大きくなり, 加入者の努力水準が上限に達して $X(t)$ の延伸がそれ以上望めなくなっても，加入者への報奨 $\gamma(t)$ が高くなればさらに大きくなるが， $\gamma(t)$ が高すぎると加入者への報奨支払い後の保険者の収益が費用を下回る可能性があるからである，従って， 保険者にとって加入者に $\Omega(W(t))$ を支払ってウェルネス・プログラムを解約する方が有利となるような $W(t)$ の水準が存在する。これを $W^{\sharp}>0$ とする．保険者が加入者に報奨の上限 $\bar{\gamma}(t)$ を与え続けるとき の継続価值を $\overline{W^{\sharp}}$ とすると， $W^{\sharp} \leq \overline{W^{\sharp} て ゙ あ る . ~}$

\section{3 最適問題の解}

本節では，前節の定式化の下での保険者の最適問題を分析する.

\section{1 最適報奨, 最適努力及び最適サポート}

まず，加入者の継続価值について，次の命題が成り立つ。証明は付録 $\mathrm{A}$ を参照.

命題 1 任意の報奨 $\gamma=\{\gamma(t)\}$, 健康サポートサービス $\mu=\{\mu(t)\}$ 及び加入者の努力 $\eta=\{\eta(t)\}$ に対 し, 時刻 $t$ における加入者の継続価值が $(7)$ 式で定義されるとき, $\mathcal{F}(t)$ 可測な適合過程 $\{Y(t)\}$ が存在 し, $W(t ; \gamma, \mu, \eta)$ は以下のように展開される：

$$
d W(t ; \gamma, \mu, \eta)=[r W(t ; \gamma, \mu, \eta)-u(\gamma(t))+h(\eta(t))] d t+\sigma Y(t) d Z(t) .
$$

次に，加入者の努力にかかる誘因両立制約について，次の命題が成り立つ. 証明は付録 B を参照.

命題 $2 Y(t)$ を命題 1 で得られる適合過程とする.このとき，加入者の努力 $\eta$ は，

$$
\eta(t) \in \underset{\tilde{\eta}(t) \in[0, \bar{\eta}]}{\arg \max }[g(\mu(t), \tilde{\eta}(t)) L(t) Y(t)-h(\tilde{\eta}(t))], 0 \leq t<\infty
$$

が成り立てば最適である.

命題 2 から， $\{Y(t)\}$ が $\eta$ に関して $W(t ; \gamma, \mu, \eta)$ を表現する過程ならば， $Y(t)$ は

$$
Y(t)=\frac{h^{\prime}(\eta(t))}{g_{\eta}(\mu(t), \eta(t)) L(t)}=y(\mu(t), \eta(t))>0 .
$$

$y(\mu(t), \eta(t))$ は $\eta(t)$ に関して増加する. なぜなら, $h(\eta(t))$ は仮定から凸関数だから $h^{\prime}(\eta(t))$ は $\eta(t)$ に関し て増加し, また $g(\mu(t), \eta(t))$ は仮定から $\eta(t)$ に関して凹だから $g_{\eta}(\mu(t), \eta(t)) L(t)$ は $\eta(t)$ に関して減少す るので, $y(\mu(t), \eta(t))$ は $\eta(t)$ について増加する。 (9) 式の（ $\sigma$ で大きさ調整された） $Y(t)$ は, $W(t ; \gamma, \mu, \eta)$ の過程のボラティリティだから， $\eta(t)$ が大きくなるほど加入者のリスクは大きくなる.

(9) 式と (11) 式から， $W$ が時刻 $t$ 時点の状態と $t$ 以降の $(\gamma, \mu, \eta)$ にのみ依存することがわかる.

\section{2 リスク-センシティブ確率制御問題}

ここで，対数関数の単調性を用いて，保険者は効用 (6) 式の最大化問題と同等な，以下の評価関数の 最大化問題を解くものとする： 


$$
\begin{array}{r}
J(W)=-\rho^{-1} \ln \left(-\mathbb{E}^{\eta}\left\{-\exp \left[-\rho \int_{t}^{\infty} e^{-r(s-t)}((1-\beta) g(\mu(s), \eta(s)) L(s)\right.\right.\right. \\
-\gamma(s)-c(\mu(t))) d s]+1\}+1) .
\end{array}
$$

これにより，問題の目的関数を解約時の值関数 $\Omega(\cdot)$ と同じ単位で測ることができるようになる.

今, 時刻 $t$ における加入者の継続価值 $W(t)$ がわかっており, 加入者が最適な努力 $\eta(t)$ を遂行し, 保 険者が報奨 $\gamma(t)$ を適切に設定すると共に最適なサポートサービス $\mu(t)$ を提供するときの, 加入者の誘因 両立制約を満たす保険者の効用最大化問題を次のリスク-センシティブ確率制御問題として定式化する：

$$
\Pi(W)=\max _{\gamma, \mu, \eta} J(W)=-\rho^{-1} \ln (-\psi(W)+1)
$$

subject to

$$
d W(t)=[r W(t ; \gamma, \mu, \eta)-u(\gamma(t))+h(\eta(t))] d t+\sigma y(\mu(t), \eta(t)) d Z(t) .
$$

但し，

$$
\psi(W)=\max _{\gamma, \mu, \eta} \mathbb{E}^{\eta}\left\{-\exp \left[-\rho \int_{t}^{\infty} e^{-r(s-t)}((1-\beta) g(\mu(s), \eta(s)) L(s)-\gamma(s)-c(\mu(s))) d s\right]+1\right\} .
$$

さらに, $\Psi(W)=\psi(W)-1$ とする.すなわち，

$$
\Psi(W)=\max _{\gamma, \mu, \eta} \mathbb{E}^{\eta}\left\{-\exp \left[-\rho \int_{t}^{\infty} e^{-r(s-t)}((1-\beta) g(\mu(s), \eta) L(s)-\gamma(s)-c(\mu(t))) d s\right]\right\} .
$$

この問題を動的計画法により解くこととし，このために，次の Hamilton-Jacobi-Bellman (HJB) 方程 式を用いる：

$$
\begin{aligned}
\max _{\gamma, \mu, \eta}\{[r W-u(\gamma) & +h(\eta)] \Psi^{\prime}(W)+\frac{1}{2} \sigma^{2} y(\mu, \eta)^{2} \Psi^{\prime \prime}(W) \\
& -\rho[(1-\beta) g(\mu, \eta) L-\gamma-c(\mu)] \Psi(W)\}=0 .
\end{aligned}
$$

\section{3 リスク-センシティブ確率制御問題の解}

この問題には一意で有界な解が存在し, かつ, その時 (17) 式を最大化する努力, サポートサービス及 び報奨は保険者の効用最大化問題の解となる.このことは次の命題によって保証される. 証明は付録 $\mathrm{C}$ を参照.

命題 3 保険者のリスク-センシティブ確率最適制御問題 $(13)-(14)$ 式において, 值関数 $\Psi(W(t))$ が $(16)$ 式によって定義されるとき，HJB 方程式 (17) 式は一意で有界な解を持ち，さらに，HJB 方程式 (17) 式 を満足する報奨 $\gamma(t)$, サポートサービス $\mu(t)$ 及び努力 $\eta(t)$ が $t \in[0, \infty)$ において対応する継続価值 $W(t)$ に関して実行可能ならば, 報奨 $\gamma(t)$, サポートサービス $\mu(t)$ 及び努力 $\eta(t)$ は保険者の効用最大化問題の 最適解である。 
さて, 対数関数の単調性から, $(W)$ は $\Psi(W)$ と同様の性質を持ち, 従って, 一意で有界な解を持つ.

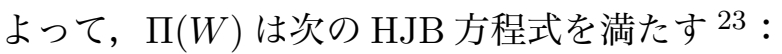

$$
\begin{aligned}
\max _{\gamma, \mu, \eta}\{[r & W-u(\gamma)+h(\eta)] \Pi^{\prime}(W)+\frac{1}{2} \rho \sigma^{2} y(\mu, \eta)^{2}\left(\Pi^{\prime}(W)\right)^{2} \\
& \left.+\frac{1}{2} \sigma^{2} y(\mu, \eta)^{2} \Pi^{\prime \prime}(W)+[(1-\beta) g(\mu, \eta) L-\gamma-c(\mu)]\right\}=0 .
\end{aligned}
$$

従って, 保険者の問題は HJB 方程式 (18) 式の解を求めることに帰着する.さらに，解は以下の初期条 件，及びバリュー・マッチング条件，スムース・ペイスティング条件を満たさなければならない：

$$
\begin{aligned}
& \Pi(0)=0, \\
& \Pi\left(W^{\sharp}\right)=-\Omega\left(W^{\sharp}\right), \\
& \Pi^{\prime}\left(W^{\sharp}\right)=-\Omega^{\prime}\left(W^{\sharp}\right) .
\end{aligned}
$$

(18) 式から，加入者に遂行させたい最適努力は

$$
\eta=\underset{\tilde{\eta}}{\arg \max }\left[h(\tilde{\eta}) \Pi^{\prime}(W)+\frac{1}{2} \rho \sigma^{2} y(\mu, \tilde{\eta})^{2}\left(\Pi^{\prime}(W)\right)^{2}+\frac{1}{2} \sigma^{2} y(\mu, \tilde{\eta})^{2} \Pi^{\prime \prime}(W)+(1-\beta) g(\mu, \tilde{\eta}) L\right]
$$

であり，その 1 階条件

$$
h^{\prime}(\eta) \Pi^{\prime}(W)+\rho \sigma^{2} y(\mu, \eta) y_{\eta}(\mu, \eta)\left(\Pi^{\prime}(W)\right)^{2}+\sigma^{2} y(\mu, \eta) y_{\eta}(\mu, \eta) \Pi^{\prime \prime}(W)+(1-\beta) g_{\eta}(\mu, \eta) L=0
$$

から最適努力水準を $W(t)$ 及び $\mu(t)$ の関数 $\eta(W(t), \mu(t))$ として求められる.ここで, $(22)$ 式の $(1-$ $\beta) g(\mu, \eta) L$ は収益で, $-h(\eta) \Pi^{\prime}(W)$ は加入者の努力に要する費用の補償である. また, $-\frac{1}{2} \sigma^{2} y(\eta(t))^{2} \Pi^{\prime \prime}(W)$ は不確実性のある健康改善努力を遂行するにあたり加入者に支払われるべきリスク・プレミアムだが, これは第 2 項の $-\frac{1}{2} \rho \sigma^{2} y(a, \mu)^{2}\left(\Pi^{\prime}(W)\right)^{2}$ によって割り引かれている ${ }^{24}$.

同様に，最適な報奨は

$$
\gamma=\underset{\tilde{\gamma}}{\arg \max }\left[-u(\tilde{\gamma}) \Pi^{\prime}(W)-\tilde{\gamma}\right]
$$

であり, 1 階条件 $\Pi^{\prime}(W)=-\frac{1}{u^{\prime}(\gamma)}$ から, $W(t)$ の関数 $\gamma(W(t))$ として得られる. $\Pi^{\prime}(W)$ は加入者の継続 価值を 1 単位増加させることによる保険者の収益の減少分, $\frac{1}{u^{\prime}(\gamma)}\left(=\frac{d \gamma}{d u(\gamma)}\right)$ は加入者の効用を 1 単位上 昇させるために保険者が加入者に与えるべき報奨で, 最適解においてはこれらが一致していなければな

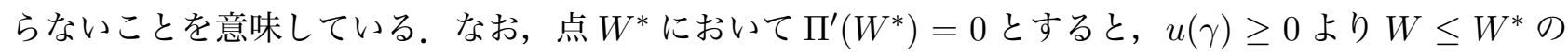
区間で $(23)$ 式を最大化する報奨は 0 となる.

そして，最適なサポートサービスは

$$
\mu=\underset{\tilde{\mu}}{\arg \max }\left\{\frac{1}{2} \rho \sigma^{2} y(\tilde{\mu}, \eta)^{2}\left(\Pi^{\prime}(W)\right)^{2}+\frac{1}{2} \sigma^{2} y(\tilde{\mu}, \eta)^{2} \Pi^{\prime \prime}(W)+[(1-\beta) g(\tilde{\mu}, \eta) L-c(\tilde{\mu})]\right\}
$$

となり，その 1 階条件

\footnotetext{
23 導出は付録 $\mathrm{D}$ を参照.

${ }^{24}-\frac{1}{2} \rho \sigma^{2} y(a, \mu)^{2}\left(\Pi^{\prime}(W)\right)^{2}$ は典型的には $-\frac{1}{2} \sigma^{2} y(\eta(t))^{2} \Pi^{\prime \prime}(W)$ と異なる方向に動くため, リスク・プレミアムを減じる効 果がある.
} 


$$
\rho \sigma^{2} y(\mu, \eta) y_{\mu}(\mu, \eta)\left(\Pi^{\prime}(W)\right)^{2}+\sigma^{2} y(\mu, \eta) y_{\mu}(\mu, \eta) \Pi^{\prime \prime}(W)+(1-\beta) g_{\mu}(\mu, \eta) L-c^{\prime}(\mu)=0
$$

から最適サポートサービス量は $W(t)$ 及び $\eta(t)$ の関数 $\mu(W(t), \eta(t))$ として求められる.

解 $(W)$ は, (22)-(24) 式を最大化する努力と報奨, サポートサービスを HJB 方程式 (18) 式に適用 し，これを境界条件 (19)-(21) 式の下で解くことにより得られ，これは数值計算によって求められる。

\section{4 数值シミュレーションと考察}

本節では, 数值計算により実際に解が存在することを例示する.

最初に, 生存関数 $S(t)$ の関数型を, $S(t)=\exp (-\lambda t)$ と特定化する.この指数関数は, 生存時間分析 においてしばしば用いられるものである（Klein and Moeschberger [4] 等）。このとき，(1) 式は

$$
L(t)=\frac{\int_{t}^{\infty} e^{-\lambda s} d s}{e^{-\lambda t}}=\frac{\left[-\frac{1}{\lambda} \exp (-\lambda s)\right]_{t}^{\infty}}{e^{-\lambda t}}=\frac{1}{\lambda}
$$

となる。

次に，各関数及びパラメータを以下のように特定化する：

$$
\begin{aligned}
& g(\mu, \eta)=0.15 \mu+0.1 \eta, \quad u(\gamma)=\sqrt{\gamma}, \quad h(\eta)=0.5 \eta^{2}+0.5 \eta, \quad c(\mu)=12 \mu^{2} \\
& \lambda=0.1, \quad r=0.1, \quad \beta=0.1, \quad \sigma=1, \quad \xi=128.5
\end{aligned}
$$

このとき，L,y( $\mu, \eta), \mu, \eta, \gamma$ はそれぞれ以下のようになる：

$$
\begin{aligned}
& L=10, \quad y(\mu(t), \eta(t))=\eta+0.5, \quad \mu=0.05625, \\
& \eta=-\frac{0.9}{\Pi^{\prime}(W)+\rho\left(\Pi^{\prime}(W)\right)^{2}+\Pi^{\prime \prime}(W)}-0.5, \\
& u(\gamma)=\sqrt{\gamma}=-\frac{\Pi^{\prime}(W)}{2}, \quad \gamma=\frac{\left(\Pi^{\prime}(W)\right)^{2}}{4} .
\end{aligned}
$$

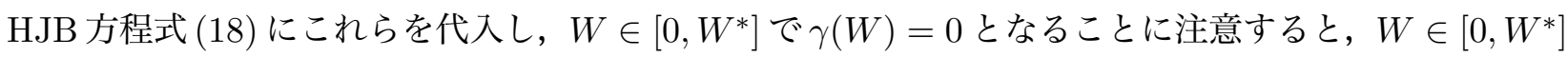
においては

$$
\Pi^{\prime \prime}(W)=\frac{1.62}{0.4 W \Pi^{\prime}(W)-0.5 \Pi^{\prime}(W)-1.648}-\Pi^{\prime}(W)-\rho\left(\Pi^{\prime}(W)\right)^{2},
$$

$W \in\left(W^{*}, \infty\right)$ においては

$$
\Pi^{\prime \prime}(W)=\frac{1.62}{0.4 W \Pi^{\prime}(W)-0.5 \Pi^{\prime}(W)+\left(\Pi^{\prime}(W)\right)^{2}-1.648}-\Pi^{\prime}(W)-\rho\left(\Pi^{\prime}(W)\right)^{2} .
$$

が得られる. また, 解約後の值関数は $\Omega(W)=-\frac{W^{2}}{\sqrt{128.5}}$ となる.

数值解は, これらの微分方程式と初期条件 (19) 式, バリュー・マッチング条件 (20) 式, スムース・ペイス ティング条件 (21) 式から, 数值計算によって得られる. $\rho=0.1$ のとき, $W^{*}=1.206, \Pi\left(W^{*}\right)=1.08856$, $\eta\left(W^{*}\right)=0.41555$ となり, $\mu$ は一定值 $\mu=0.05625$ となった（図 1 参照）. 
医療保険加入者に健康改善への行動変容を促すウェルネス・プログラムの 最適インセンティブ設計
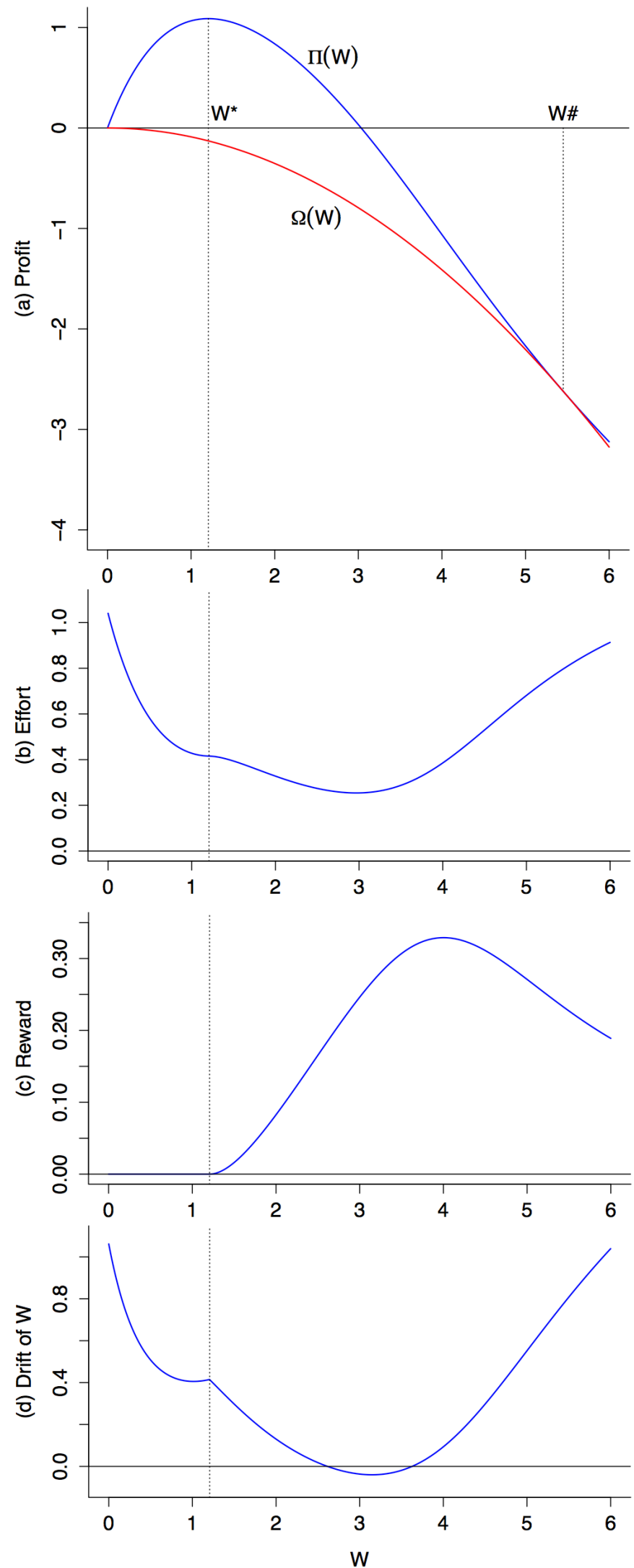

図 1: $\rho=0.1$ のときの (a) 保険者の収益 $\Pi(W),(\mathrm{b})$ 加入者の努力 $\eta(W),(\mathrm{c})$ 報奨 $\gamma(W),(\mathrm{d}) W$ のドリ フト 
值関数 $\Pi(W)$ の $W=0$ における傾き $\Pi^{\prime}(0)$ は様々な值をとり得るが，バリュー・マッチング条件 $(20)$ 式，スムース・ペイスティング条件 $(21)$ 式を満たす值は一意に定まる。 $\Pi(W)$ は $W=3.035$ で負とな り, $W^{\sharp}=5.451$ で解約後の值関数 $\Omega(W)$ と接する。 $W^{\sharp} よ り$ 右側で $\Pi(W)$ は $\Omega(W)$ と交わることはな く, 乘離していく. 実際, (18) 式を

$$
\Pi^{\prime \prime}(W)=\frac{-[r W-u(\gamma)+h(\eta)] \Pi^{\prime}(W)-\frac{1}{2} \rho \sigma^{2} y(\mu, \eta)^{2}\left(\Pi^{\prime}(W)\right)^{2}-[(1-\beta) g(\mu, \eta) L-\gamma-c(\mu)]}{\frac{1}{2} \sigma^{2} y(\mu, \eta)^{2}}
$$

のように変形して確認してみると, $\Pi^{\prime}(W) \geq 0$ の区間では $\Pi^{\prime \prime}(W)<0$ であるが, $\Pi^{\prime}(W)<0$ の区間で

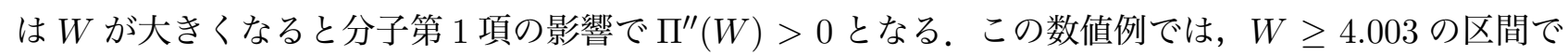
$\Pi^{\prime \prime}(W)>0$ となった.

最適インセンティブ・メカニズムは, 改善努力スケジュール $\eta(W)$ と報奨メニュー $\gamma(W)$ から構成され る. ウェルネス・プログラムの提供にあたり, 保険者は加入者に対して到達目標として加入者の将来期 待効用 $W^{*}$ と $\eta\left(W^{*}\right)$, 並びに努力スケジュール $\eta(W)$ を提示し, これを達成するよう強く推奨する. 努 力 $\eta(W)$ は, 具体的には血圧や血糖值, BMI，コレステロール值など保険者が観測かつ測定可能な指標 值の改善度によって表される。保険者が加入者にウェルネス・プログラムを開始する時点 $t=0$ におい

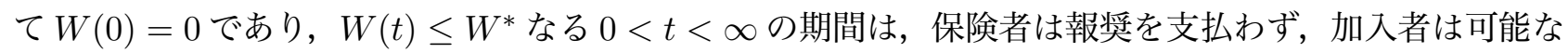
限り短期間で $W(t)=W^{*}$ となるように推奨された $\eta(W)$ に従い健康改善努力を遂行する. 加入者の努 力によって $W(t)$ は $(9)$ 式に従い展開され, やがて $W^{*} に$ 到達すると, 加入者は保険者から $\eta\left(W^{*}\right)$ の努 力水準を維持するよう推奨される. 加入者が改善努力 $\eta\left(W^{*}\right)$ を維持する限り, 加入者の継続価值は $W^{*}$ にとどまり，保険者は П $\left(W^{*}\right)$ の収益を得ることになる.

もし, 加入者の努力水準が $\eta\left(W^{*}\right)$ より低くなると $W$ は $W^{*}$ を超え, 保険者の収益は $\Pi\left(W^{*}\right)$ を下回つ てしまう。この場合，保険者は $\gamma(W)$ の報奨を加入者に前払いする。 $\gamma(W)$ が支払われると $W$ の゙リフ トは減少し, さらに報償が大きくなるとドリフトはやがて負となり $W$ は減少する. それは加入者の将来 の期待効用の減少を意味し, 長期的な効用最大化を求める加入者にとっては望ましいことではない. 加 入者が期待効用を拡大するためには再び努力水準を高める必要があり，その結果 $W$ は $W^{*}$ に復帰する. こうして， $\mu, \eta, \gamma$ が最適に制御されることにより，保険者の収益，すなわち抑制された保険金支払額は 最適值 $\left(W^{*}\right)$ が実現される.

なお，健康サポートサービスは加入者の努力遂行に直接的には効いていない．加入者の誘引両立制約 から加入者の健康改善行動に影響を及ぼすのは報奨のみなので, 保険者がウェルネス・プログラムの費 用を削減し収益を拡大するためには，健康サポートサービスを提供しない方がよいようにも思える。し かしながら, 健康寿命影響度関数 $g(\mu, \eta)$ について仮定したように, 健康改善努力がなされなくとも健康 サポートサービスによって健康寿命が延伸するなら, 加入者の努力度によらず保険者がサポートサービ スを提供することに合理性はある. 多くの自治体や保険組合が web やセミナー等を通じて加入者向けに 健康や医療に関する情報提供を実施しているが, これらは健康改善のための積極的な努力遂行には繋が らないまでも，知識不足を原因とする不健康な行為を防止する効果が期待される ${ }^{25}$.

健康寿命は血糖值や BMI などによって推定可能だが，これらの指標は必ずしも短期間で改善できると は限らず，これらのみで健康改善努力の大きさを測るものとすると, 加入者に健康改善のモチベーショ ンを維持させることが難しくなる. 運動量や摂取カロリー量など, 加入者が短期的に達成感の得られる 指標も含めることがモチベーション維持には効果的であり, 実際のプログラム設計ではこれらの指標を 適切な加重付けを行って $g(\mu, \eta)$ を設定する必要がある. しかし, 運動量等は原則として加入者の自己申 告となるため，データの信頼性や本人性の確保等が実務上の課題となる ${ }^{26}$.

25例えば，発がん物質の摂取を避ける等.

26 運動量に限らず，血圧や血糖值，BMI はウェアラブル端末や自己採血キットなどを用いて加入者本人によって測定可能で， 


\section{5 リスク感度分析}

本論文では保険者はリスク回避的と仮定しているが，リスク感度自体は様々な值をとるケースが考え られる。本節では，リスク感度 $\rho$ の差異が最適解に与える影響を分析する。

図 2 はリスク感度をそれぞれ $\rho=0.05,0.1,0.15$ としたときの保険者の収益 $\Pi(W)$, 加入者の努力 $\eta(W)$, 並びに報奨 $\gamma(W)$ を示している．また，表 1 は各リスク感度における $W^{*}, \Pi\left(W^{*}\right), \eta\left(W^{*}\right), \Pi^{\prime}(0), \eta(0)$ の 值である.

シミュレーションの結果，リスク感度 $\rho$ が大きい，すなわち，よりリスク回避的であるほど収益 $\Pi\left(W^{*}\right)$ は大きくなった。 $\eta\left(W^{*}\right)$ は $\rho$ の值によらず同一だが，これは $\Pi^{\prime}\left(W^{*}\right)=0$ より，(22) 式において $\rho$ を含 む項が消えてしまうからである。また， $W^{*}, \Pi^{\prime}(0), \eta(0)$ も $\rho$ が大きいほど大きい 27 .これは, 次のよう に解釈できる。

(i) $\rho$ が大きくなるほど $\Pi^{\prime}(0), \eta(0)$ が大きいということは, リスク回避的な保険者ほどウェルネス・プ ログラム開始当初に加入者により高い努力を求めることを意味する.

(ii) $\rho$ が大きくなるほど $W^{*}$ が大きいということは，Wが $W^{*}$ に到達するまで報奨が支払われないこ とから，リスク回避的な保険者ほど報奨の支払いを遅らせることを意味する.

さらに，(i) は加入者の継続価値 $W(t)$ の確率過程のボラティリティを高め $((11)$ 式を参照) , 従って加 入者のリスクを増大させることを意味している。

(i), (ii) から，よりリスク回避的な保険者が提供するウェルネス・プログラムに参加できるのは，プロ グラム開始時により大きな努力を行うことができ，かつ，努力にも関わらず健康寿命が拡大しないとい うリスクの受容度が大きく，そして，報奨の支払いまでより長期間待つことのできる（但し，より大き な期待効用を享受できる）加入者ということになる。このような加入者は保険者にとって優良顧客であ るから，リスク回避的な保険者ほど優良顧客を集めるということである．逆に言えば，これは，大きな 努力のできない，すなわち健康寿命を伸ばす意欲の低い加入者はこのプログラムから排除されることを 意味する．しかしながら，本来このウェルネス・プログラムに参加させたいのは，健康寿命を伸ばす意 欲の低い加入者であり，より多くの加入者に参加してもらい，結果として国民医療費の削減に繋げるた めには，保険者はリスク回避的であるべきでないことになる.

\section{6 おわりに}

本論文では，加入者に健康改善努力をさせ，健康寿命を伸ばすことで保険金支払額を抑制できる報償 提供型ウェルネス・プログラムを導入する保険者のインセンティブ・メカニズム設計問題を, 動的プリ ンシパル-エージェント・モデルとして定式化した。その結果，有界で一意な解が存在することが示され， 数值シミュレーションによって具体的に解が求められた。これにより，医療費抑制と加入者の健康寿命 延伸を実現できる最適なインセンティブ・メカニズムを設計可能であることが示された。

さらに，保険者のリスク感度分析により，リスク回避的な保険者ほど健康改善意欲の高い優良顧客を 集め，保険者の収益はより大きくなることが示された。このことは，保険者がリスク回避的であるほど， 本来ウェルネス・プログラムに参加させたいはずの低意欲の加入者を排除してしまうことを意味する. 一般的に，利益最大化を目的とする民間保険会社は公的医療保険（自治体（国民保険）等）よりもリス

医療機関等で測定を行うより加入者の負担が少なく, 費用も抑えられる.これらのデータはインターネットなどを用いて加入 者本人から報告さ机ることになるが，デー夕の改瓮や本人性の証明，個人情報保護など，実務上解決すべき課題は多い。

${ }^{27} \Pi^{\prime}(0)$ が大きいほど $\Pi(W)$ の解曲線は大きな弧を描き， $W^{*}$ も大きくなる. 

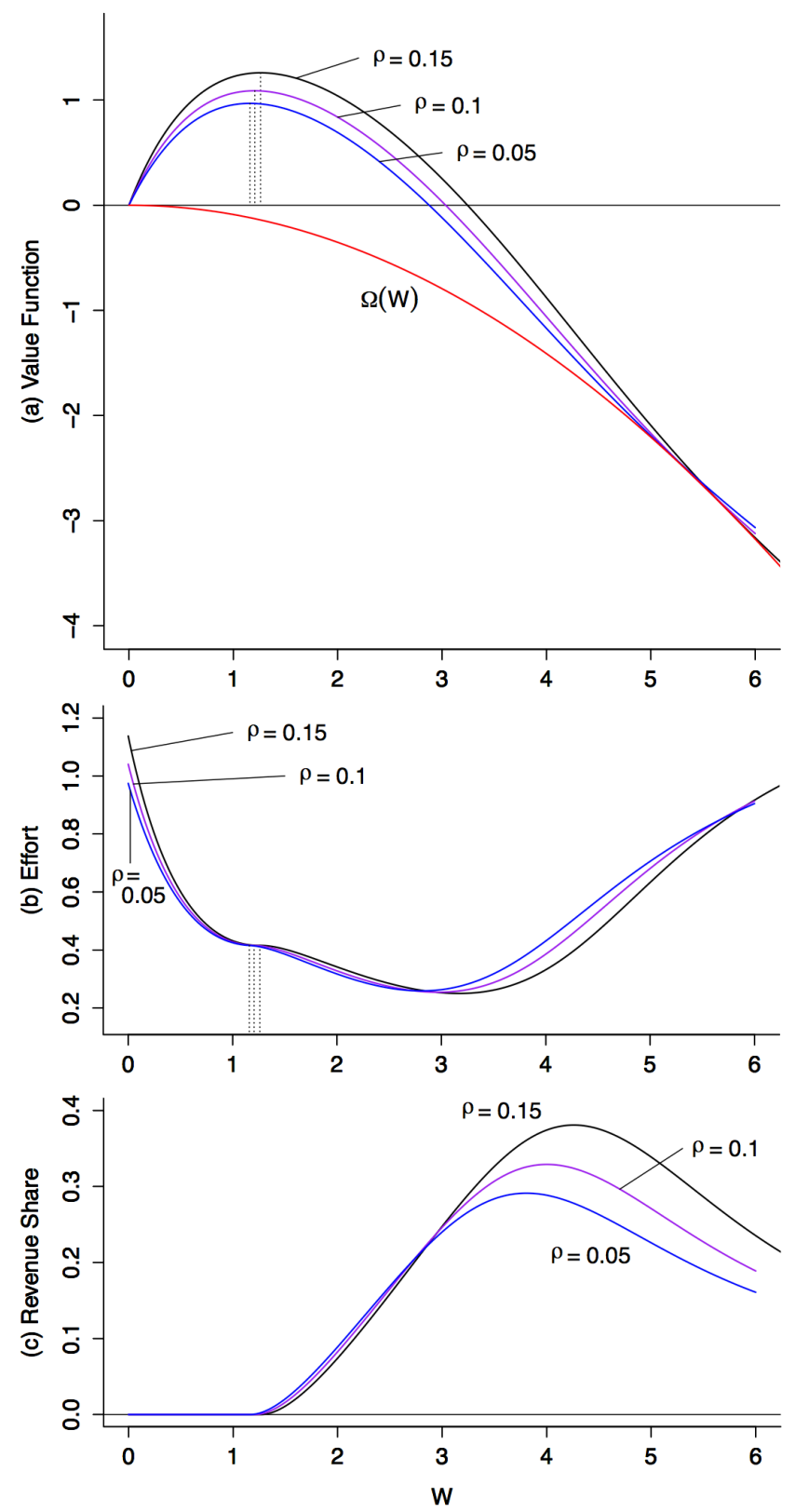

図 2: $\rho=0.05,0.1,0.15$ のときの (a) 保険者の収益 $\Pi(W),(\mathrm{b})$ 加入者の努力 $\eta(W),(\mathrm{c})$ 報奨 $\gamma(W)$

表 1: $\rho=0.05,0.1,0.15$ のときの $W^{*}, \Pi\left(W^{*}\right), \eta\left(W^{*}\right)$ 及び $\Pi^{\prime}(0), \eta(0)$

\begin{tabular}{llllll}
\hline リスク感度 & $W^{*}$ & $\Pi\left(W^{*}\right)$ & $\eta\left(W^{*}\right)$ & $\Pi^{\prime}(0)$ & $\eta(0)$ \\
\hline$\rho=0.15$ & 1.261 & 1.25949 & 0.41556 & 2.6 & 1.13778 \\
$\rho=0.1$ & 1.206 & 1.08856 & 0.41556 & 2.25 & 1.04056 \\
$\rho=0.05$ & 1.16 & 0.96867 & 0.41556 & 2.012 & 0.97444 \\
\hline
\end{tabular}


ク回避度が高いと想定されるが，もしそうであれば，比較的リスク許容度の大きな公的保険からウェル ネス・プログラムを推進していくのが望ましいとも考えられる。しかし，将来的には報償の設定などに おいてょり自由度の高い民間医療保険が多様なウェルネス・プログラムを提供していくことが必要であ ると思われる ${ }^{28}$. なお，本論文のモデルは定義上保険者がリスク中立的 $(\rho=0)$ となるケースは対象外 となるが， $\rho$ を非常に小さい值にとることで保険者がリスク中立的であるケースを近似できる.

本論文では分析を簡単にするため, 健康寿命のダイナミクスがブラウン運動に従うと仮定した。健康 寿命の推計はこれまでも試みられているが 29 , 健康寿命のダイナミクスは必ずしも十分実証されている 状況にないと思われ，今後ダイナミクスが従う確率過程についての実証研究が待たれるところである.

また，本論文では代表的な 1 人の加入者を想定し，保険者の収益はその 1 人の加入者から得られるも のとしており，その代表加入者の健康改善意欲の高さについて特に限定していない. しかし，現実には， ウェルネス・プログラムの参加対象となり得る加入者集合の中に, 健康改善意欲の異なる顧客が均一に 分布しているとは限らない. もし, 低意欲の加入者が偏在しているなら，よりリスク中立的にインセン ティブ・メカニズムを設計することにより，リスク回避的な場合よりも加入者 1 人あたりの収益は低く なったとしても, 加入者集合全体から得られる収益をより拡大できる可能性がある. 実証研究を蓄積し ていくことで，低意欲加入者を排除せず，かつ，データの信頼性や本人性の確保等などにおいて実務上 実現可能なウェルネス・プログラムを設計していくことが今後の課題である.

\section{A 命題 1 の証明}

今, 戦略 $(\gamma, \mu, \eta)$ に従っていて, 時刻 $t$ までの情報が与えられるとき，全期間における加入者の総期 待効用を

$$
V(t)=\int_{0}^{t} e^{-r s}(u(\gamma(s))-h(\eta(s))) d s+e^{-r t} W(t ; \gamma, \mu, \eta)
$$

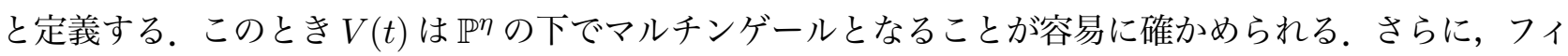
ルトレーション $\{\mathcal{F}(t)\}$ は確率過程 $d Z(t)=\frac{1}{\sigma}[d X(t)-g(\mu(t), \eta(t)) S(t) d t]$ によって生成される $\sigma$-加法 族と同一である. よって， $V(t)$ は，マルチンゲール表現定理によって，

$$
V(t)=V_{0}+\int_{0}^{t} e^{-r s} \sigma Y(s) d Z(s), 0 \leq t<\infty
$$

となる適合過程 $\{Y(t), \mathcal{F}(t) ; 0 \leq t<\infty\}$ が存在する。(25) 式，(26) 式を $t$ に関して微分すると，

$$
\begin{aligned}
d V(t) & =e^{-r t}[u(\gamma(t))-h(\eta(t))] d t+d\left[e^{-r t} W(t ; \gamma, \mu, \eta)\right] \\
& =e^{-r t}[u(\gamma(t))-h(\eta(t))-r W(t ; \gamma, \mu, \eta)] d t+e^{-r t} d W(t ; \gamma, \mu, \eta)
\end{aligned}
$$

及び

$$
d V(t)=e^{-r t} \sigma Y(t) d Z(t)
$$

\footnotetext{
28 経済産業省の平成 26 年度健康寿命延伸産業創出推進事業」において，アイアル少額短期保険株式会社がウエルネス・プロ グラムと連動した生命保険の検証事業を実施ている。

29 平成 24 年度厚生労働科学研究費補助金「健康寿命における将来予測と生活習慣病対策の費用対効果に関する研究班」に よる「健康寿命の算定方法の指針」等。
} 
となるから，

$$
d W(t ; \gamma, \mu, \eta)=[r W(t ; \gamma, \mu, \eta)-u(\gamma(t))+h(\eta(t))] d t+\sigma Y(t) d Z(t)
$$

となる。

\section{B 命題 2 の証明}

加入者が時刻 $t$ 期まで任意の代替的な努力戦略 $\tilde{\eta}=\{\tilde{\eta}(s), 0 \leq s<t\}$ に従い, $t$ 以降は戦略 $\eta=$ $\{\eta(s), t \leq s<\infty\}$ に従うときに, 時刻 $t$ における加入者の総期待効用を

$$
\hat{V}(t)=\int_{0}^{t} e^{-r s}(u(\gamma(s))-h(\tilde{\eta}(s))) d s+e^{-r t} W(t ; \gamma, \mu, \eta)
$$

と定義する. $\hat{V}(t)$ は確率測度 $\mathbb{P} \tilde{\eta}$ の下での $\tilde{\mathcal{F}}(t)$-可測な確率過程である。このとき， $\hat{V}(t)$ は，命題 1 を 利用して,

$$
\begin{aligned}
d \hat{V}(t)= & e^{-r t}[u(\gamma(t))-h(\tilde{\eta}(t))] d t+d\left[e^{-r t} W(t ; \gamma, \mu, \eta)\right] \\
= & e^{-r t}[u(\gamma(t))-h(\tilde{\eta}(t))] d t-e^{-r t} r W(t ; \gamma, \mu, \eta)+e^{-r t} d W(t ; \gamma, \mu, \eta) \\
= & e^{-r t}[u(\gamma(t))-h(\tilde{\eta}(t))] d t-e^{-r t} r W(t ; \gamma, \mu, \eta) \\
& +e^{-r t}\{[r W(t ; \gamma, \mu, \eta)-u(\gamma(t))+h(\eta(t))] d t+\sigma Y(t) d Z(t)\} \\
= & e^{-r t}(u(\gamma(t))-h(\tilde{\eta}(t))) d t-e^{-r t}(u(\gamma(t))-h(\eta(t))) d t+e^{-r t} \sigma Y(t) d Z(t) \\
= & e^{-r t}[(h(\eta(t))-h(\tilde{\eta}(t)))+(g(\mu(t), \tilde{\eta}(t))-g(\mu(t), \eta(t))) L(t) Y(t)] d t \\
& +e^{-r t} \sigma Y(t) d \tilde{Z}(t) .
\end{aligned}
$$

ここで, $\mathbb{P}$ と $\mathbb{P} \tilde{\eta}$ の下でのブラウン運動は $\sigma Z(t)=\sigma \tilde{Z}(t)+\int_{0}^{t}(g(\mu(s), \tilde{\eta}(s))-g(\mu(s), \eta(s))) L(s) d s$ で関 係づけられている。

もし， $\eta(t)$ が正の測度集合上で $(10)$ 式を満たさなければ, $g(\mu(t), \tilde{\eta}(t)) L(t) Y(t)-h(\tilde{\eta}(t))$ を最大化す る $\{\tilde{\eta}(s), 0 \leq s<t\}$ を選ぶことができる。このとき， $\hat{V}(t)$ のドリフトは非負で，かつ，正の測度集合上 で正だから，

$$
\mathbb{E}^{\{\tilde{\eta}(t)\}}[\hat{V}(t)]>\hat{V}(0)=W(0 ; \gamma, \mu, \eta)
$$

となる時刻 $t$ が存在する. $\mathbb{E}^{\{\tilde{\eta}(t)\}}[\hat{V}(t)]$ は， $t$ 期まで戦略 $\{\tilde{\eta}(t)\}$ に従い，その後戦略 $\{\eta(t)\} に$ 変更したと きに加入者が得る総期待効用であり, それが時刻 0 以降戦略 $\{\eta(t)\}$ をとる場合の総期待効用 $W(0 ; \gamma, \mu, \eta)$ を上回ることから，戦略 $\{\eta(t)\}$ は最適でない.

(10) 式が戦略 $\eta$ について成り立つなら, $\hat{V}(t)$ は任意の戦略 $\tilde{\eta}$ に対し, 優マルチンゲールとなる.さら に, 確率過程 $W(t ; \gamma, \mu, \eta)$ は下に有限であるから, $\hat{V}(t)$ の極限として

$$
\hat{V}(\infty)=\int_{0}^{\infty} e^{-r s}(u(\gamma(s))-h(\eta(s))) d s
$$


をとることができる ${ }^{30}$.よって，

$$
W(0 ; \gamma, \mu, \eta)=\hat{V}(0) \geq \mathbb{E}^{\{\tilde{\eta}(t)\}}[\hat{V}(\infty)]=W(0 ; \gamma, \mu, \tilde{\eta})
$$

が成り立つ。よって，戦略 $\eta$ は任意の戦略 $\tilde{\eta}$ と少なくとも同等に望ましくなる.

\section{C 命題 3 の証明}

保険者の問題の仮定及び (11) 式から，以下の条件

(i) $\{\gamma(t)\},\{\mu(t)\},\{\eta(t)\}$ は有界かつ閉集合，

(ii) $[r W-u(\gamma(t))+h(\eta(t))]$ は, $(W(t), \gamma(t), \eta(t)) \in\left[0, \overline{W^{\sharp}}\right] \times[0, \bar{\gamma}(t)] \times[0, \bar{\eta}]$ において有界で連続微分可 能，かつその 1 階微分も有界，また， $[(1-\beta) g(\mu(t), \eta(t)) L(t)-\gamma(t)-c(\mu(t))]$ は， $(\gamma(t), \mu(t), \eta(t)$, $L(t)) \in[0, \bar{\gamma}(t)] \times[0, \bar{\mu}] \times[0, \bar{\eta}] \times[0, \bar{L}]$ において有界で連続微分可能，かつその 1 階微分も有界，

(iii) $y(\mu(t), \eta(t))$ は $(\mu(t), \eta(t)) \in[0, \bar{\mu}] \times[0, \bar{\eta}]$ において連続微分可能で，かつ $y(\mu(t), \eta(t))^{2}>0$ が成り立つ. 従って, Fleming and Soner [2] の定理 IV.4.1より HJB 方程式 (17) 式は一意な解を持つ. 次に, $\gamma^{*}(t), \mu^{*}(t), \eta^{*}(t)$ が (15) 式の解であるとする。このとき, (15) 式より ${ }^{31}$

$$
\begin{aligned}
& \psi(W(t)) \\
& =\max _{\gamma, \mu, \eta} \mathbb{E}^{\eta}\left\{-\exp \left[-\rho \int_{t}^{\infty} e^{-r(s-t)}((1-\beta) g(\mu(s), \eta(s)) L(s)-\gamma(s)-c(\mu(s))) d s\right]+1\right\} \\
& =\max _{\gamma, \mu, \eta} \mathbb{E}^{\eta}\left\{-\exp \left[-\rho \int_{t}^{t+\Delta t} e^{-r(s-t)}((1-\beta) g(\mu(s), \eta(s)) L(s)-\gamma(s)-c(\mu(s))) d s\right]\right. \\
& \times \underbrace{\exp \left[-\rho \int_{t+\Delta t}^{\infty} e^{-r(s-t-\Delta t)}((1-\beta) g(\mu(s), \eta(s)) L(s)-\gamma(s)-c(\mu(s))) d s\right]}_{-\psi(W(t+\Delta t))+1}+1\} \\
& =\max _{\gamma, \mu, \eta} \mathbb{E}^{\eta}\left\{-\exp \left[-\rho \int_{t}^{t+\Delta t} e^{-r(s-t)}((1-\beta) g(\mu(s), \eta(s)) L(s)-\gamma(s)-c(\mu(s))) d s\right]\right. \\
& \times(-\psi(W(t+\Delta t))+1))+1\} \\
& =\max _{\gamma, \mu, \eta} \mathbb{E}^{\eta}\left\{\left[-1+\rho e^{-r \Delta t}((1-\beta) g(\mu(t), \eta(t)) L(t)-\gamma(t)-c(\mu(t))) \Delta t\right]\right. \\
& \times(-\psi(W(t))-\Delta \psi(W(t))+1)+1\} \\
& =\max _{\gamma, \mu, a} \mathbb{E}^{\eta}\{\psi(W(t))+\Delta \psi(W(t))-1 \\
& -\rho e^{-r \Delta t}((1-\beta) g(\mu(t), \eta(t)) L(t)-\gamma(t)-c(\mu(t))) \psi(W(t)) \Delta t \\
& -\rho e^{-r \Delta t}((1-\beta) g(\mu(t), \eta(t)) L(t)-\gamma(t)-c(\mu(t))) \Delta \psi(W(t)) \Delta t \\
& \left.+\rho e^{-r \Delta t}((1-\beta) g(\mu(t), \eta(t)) L(t)-\gamma(t)-c(\mu(t))) \Delta t+1\right\}
\end{aligned}
$$

\footnotetext{
${ }^{30}$ Karatzas and Shreve(1991) [3] の問題 3.16 を参照.

${ }^{31} e^{x}$ の無限級数展開 $e^{x}=1+x+\frac{x^{2}}{2 !}+\cdots$ を用いている（3 項目以降は無視できるので, 最初の 2 項のみ用いている).
} 


$$
\begin{aligned}
& =\max _{\gamma, \mu, a} \mathbb{E}^{\eta}\{\psi(W(t))+\Delta \psi(W(t)) \\
& -\rho(1-r \Delta t)((1-\beta) g(\mu(t), \eta(t)) L(t)-\gamma(t)-c(\mu(t))) \psi(W(t)) \Delta t \\
& -\rho(1-r \Delta t)((1-\beta) g(\mu(t), \eta(t)) L(t)-\gamma(t)-c(\mu(t))) \Delta \psi(W(t)) \Delta t \\
& +\rho(1-r \Delta t)((1-\beta) g(\mu(t), \eta(t)) L(t)-\gamma(t)-c(\mu(t))) \Delta t\} \\
& =\max _{\gamma, \mu, a} \mathbb{E}^{\eta}\{\psi(W(t))+\Delta \psi(W(t)) \\
& -\rho((1-\beta) g(\mu(t), \eta(t)) L(t)-\gamma(t)-c(\mu(t))) \psi(W(t)) \Delta t \\
& +\operatorname{\rho r}((1-\beta) g(\mu(t), \eta(t)) L(t)-\gamma(t)-c(\mu(t))) \psi(W(t))(\Delta t)^{2} \\
& -\rho((1-\beta) g(\mu(t), \eta(t)) L(t)-\gamma(t)-c(\mu(t))) \Delta \psi(W(t)) \Delta t \\
& +\rho r((1-\beta) g(\mu(t), \eta(t)) L(t)-\gamma(t)-c(\mu(t))) \Delta \psi(W(t))(\Delta t)^{2} \\
& -\rho((1-\beta) g(\mu(t), \eta(t)) L(t)-\gamma(t)-c(\mu(t))) \Delta t \\
& \left.+\rho r((1-\beta) g(\mu(t), \eta(t)) L(t)-\gamma(t)-c(\mu(t)))(\Delta t)^{2}\right\} \text {. }
\end{aligned}
$$

ここで, $\Delta t \rightarrow 0$ とすると， $(\Delta t)^{2}$ 及び $\Delta \psi(W(t)) \Delta t$ は $\Delta t$ より急速に 0 に近づくので, これらが含まれ る項は消去でき,

$$
\begin{aligned}
\psi(W(t))=\max _{\gamma, \mu, \eta} \mathbb{E}^{\eta}\{\psi(W(t))+d \psi(W(t)) \\
-\rho((1-\beta) g(\mu(t), \eta(t)) L(t)-\gamma(t)-c(\mu(t)))(\psi(W(t))-1) d t\} .
\end{aligned}
$$

よって,

$$
\max _{\gamma, \mu, a} \mathbb{E}^{\eta}\{d \psi(W(t))-\rho((1-\beta) g(\mu(t), \eta(t)) L(t)-\gamma(t)-c(\mu(t)))(\psi(W(t))-1) d t\}=0 .
$$

さらに，伊藤の公式から

$$
\begin{aligned}
d \psi(W(t))= & \left\{[r W(t)-u(\gamma(t))+h(\eta(t))] \psi^{\prime}(W(t))+\frac{1}{2} \sigma^{2} y(\mu(t), \eta(t))^{2} \psi^{\prime \prime}(W(t))\right\} d t \\
& +\sigma y(\mu(t), \eta(t)) \psi^{\prime}(W(t)) d Z(t) .
\end{aligned}
$$

よって, HJB 方程式

$$
\begin{aligned}
\max _{\gamma, \mu, \eta}\left\{[r W(t)-u(\gamma(t))+h(\eta(t))] \psi^{\prime}(W(t))+\frac{1}{2} \sigma^{2} y(\mu(t), \eta(t))^{2} \psi^{\prime \prime}(W(t))\right. \\
-\rho((1-\beta) g(\mu(t), \eta(t)) L(t)-\gamma(t)-c(\mu(t)))(\psi(W(t))-1)\}=0
\end{aligned}
$$

が得られる。ここで,

$$
\Psi(W(t))=\psi(W(t))-1, \quad \Psi^{\prime}(W(t))=\psi^{\prime}(W(t)), \quad \Psi^{\prime \prime}(W(t))=\psi^{\prime \prime}(W(t))
$$


より，

$$
\begin{aligned}
\max _{\gamma, \mu, \eta}\left\{[r W(t)-u(\gamma(t))+h(\eta(t))] \Psi^{\prime}(W(t))+\frac{1}{2} \sigma^{2} y(\mu(t), \eta(t))^{2} \Psi^{\prime \prime}(W(t))\right. \\
-\rho((1-\beta) g(\mu(t), \eta(t)) L(t)-\gamma(t)-c(\mu(t))) \Psi(W(t))\}=0
\end{aligned}
$$

が得られる。従って, $\gamma^{*}(t), \mu^{*}(t), \eta^{*}(t)$ は $(17)$ 式の解である。すなわち，(17) 式を満たす報奨とサポー トサービス及び努力は効用最大化問題の解である.

\section{D (18) 式の導出}

$$
\begin{aligned}
& \Pi(W)=-\rho^{-1} \ln (-\Psi(W)) \text { より } \\
& \Pi^{\prime}(W)=-\rho^{-1} \frac{-\Psi^{\prime}(W)}{-\Psi(W)}=-\rho^{-1} \frac{\Psi^{\prime}(W)}{\Psi(W)} \Rightarrow \Psi^{\prime}(W)=-\rho \Pi^{\prime}(W) \Psi(W), \\
& \Psi^{\prime \prime}(W)=-\rho \Pi^{\prime \prime}(W) \Psi(W)-\rho \Pi^{\prime}(W) \Psi^{\prime}(W) \\
& =-\rho \Pi^{\prime \prime}(W) \Psi(W)-\rho \Pi^{\prime}(W)\left(-\rho \Pi^{\prime}(W) \Psi(W)\right) \\
& =-\rho \Pi^{\prime \prime}(W) \Psi(W)-\rho^{2}\left(\Pi^{\prime}(W)\right)^{2} \Psi(W) .
\end{aligned}
$$

これらを(17) 式に代入すると

$$
\begin{aligned}
\max _{\gamma, \mu, \eta}\left\{[r W-u(\gamma)+h(\eta)]\left(-\rho \Pi^{\prime}(W) \Psi(W)\right)\right. \\
+\frac{1}{2} \sigma^{2} y(\mu, \eta)^{2}\left[-\rho \Pi^{\prime \prime}(W) \Psi(W)-\rho^{2}\left(\Pi^{\prime}(W)\right)^{2} \Psi(W)\right] \\
\quad-\rho[(1-\beta) q(\mu, \eta) L-\gamma-c(\mu)] \Psi(W)\}=0
\end{aligned}
$$

ここで両辺を $-\rho \Psi(W)$ で除すると

$$
\begin{aligned}
\max _{\gamma, \mu, \eta}\left\{[r W-u(\gamma)+h(\eta)] \Pi^{\prime}(W)+\frac{1}{2} \rho \sigma^{2} y(\mu, \eta)^{2}\left(\Pi^{\prime}(W)\right)^{2}+\frac{1}{2} \sigma^{2} y(\mu, \eta)^{2} \Pi^{\prime \prime}(W)\right. \\
+[(1-\beta) g(\mu, \eta) L-\gamma-c(\mu)]\}=0
\end{aligned}
$$

が得られる。

\section{参考文献}

[1] Başar, T. and Bernhard, P. (1995): $H^{\infty}$-Optimal Control and Related Minimax Design Problems A Dynamic Game Approach, 2nd Edition, Birkhäuser.

[2] Fleming, W. H. and Soner, H. M. (2006): Controlled Markov Processes and Viscosity Solutions, 2nd Edition, Springer Verlag, New York. 
[3] Karatzas, L. and Shreve, S. (1991): Brownian Motion and Stochastic Calculus, Springer-Verlag.

[4] Klein, J. P. and Moeschberger, M. L. (2003): Survival Analysis, 2nd Edition, Springer Science+Business Media.

[5] Lambert, E. V., da Silva, R., Patel, D., Fatti, L., Kolbe-Alexander, T., Noach, A., Nossel, C., Derman, W. and Gaziano, T. (2006): Fitness-Related Activities and Medical Claims Related to Hospital Admissions -South Africa, 2006, Preventing Chronic Disease, 6, 1-9.

[6] Merrill, R. M., Hyatt, B., Aldana, S. G. and Kinnersley, D. (2011): Lowering Employee Health Care Costs Through the Healthy Lifestyle Incentive Program, Journal of Public Health Management 83 Practice, 17, 225-232.

[7] Patel, D., Lambert, E. V., da Silva, R., Greyling, M., Kolbe-Alexander, T., Noach, A., Conradie, J., Nossel, C., Borresen J. and Gaziano, T. (2011): Participation in Fitness-Related Activities of an Incentive-Based Health Promotion Program and Hospital Costs: A Retrospective Longitudinal Study, American Journal of Health Promotion, 25, 341-348.

[8] Sannikov, Y. (2008): A Continuous Time Version of the Principal-Agent Problem, Review of Economic Journal Studies, 75, 957-984.

[9] Vitality Health (2016): Healthy Living Rewards And Partners.

[10] Yatsuya, H., Iso, H., Li, Y., Yamagishi, K., Kokubo, Y., Saito, I., Sawada, N., Inoue M. and Tsugane, S. (2016): Development of a Risk Equation for the Incidence of Coronary Artery Disease and Ischemic Stroke for Middle-Aged Japanese -Japan Public Health Center-Based Prospective Study-, Circulation Journal, 80, 1386-1395. 